\title{
https://doi.org/10.48009/1_iis_2006_204-209 \\ UPDATING THE INFORMATION SYSTEMS CURRICULUM: THE CAMERON EXPERIENCE
}

\author{
Dr. T. K. Bhattacharya, Cameron University, topanb@ cameron.edu \\ John DiRenzo, Cameron University, johnd@ cameron.edu \\ Kimberly Merritt, Cameron University, kmerritt@cameron.edu \\ K. David Smith, Cameron University, davids@ cameron.edu
}

\begin{abstract}
In the 1990s, enrollment in the Management Information Systems (MIS) programs at universities expanded significantly, and in many universities the MIS major was the single largest major on the entire campus. Enrollment in the Cameron University $(C U)$ Business Systems program was stagnant. A team of faculty worked on completely revamping the curriculum and securing approval by the university administration and the regents. The purpose of this paper is to share the process used in updating the program and making it more relevant to students and employers. The process used is relevant not merely for developing MIS programs, but for developing and updating the curriculum in any business major.
\end{abstract}

Keywords: Information Systems, Curriculum, Learning Model, Course Design

\section{INTRODUCTION}

During the 1990s, Cameron University's (CU) information systems program was called Business Systems. Enrollment in the program was about 3.8\% of the total undergraduate business enrollment, whereas enrollment in some of the institutions surveyed averaged around $20-25$ percent. CU was clearly missing out on the strong enrollment other institutions were experiencing in their MIS programs. The primary reason for the low enrollment was the outdated curriculum.

\section{UPDATING THE CURRICULUM}

A team consisting of the Business Department Chair and the MIS faculty members started work on updating the curriculum. The first step was to define the goals of the program. The team identified the following goals:

- To prepare students for professional success across a wide array of technology professions

- To prime students for graduate work in a variety of technology disciplines
- To promote life-long learning, as it will be vital for success in rapidly changing fields

- To develop problem-solving skills

- To engender professional and ethical behaviors in students

The team examined the Computer Information Systems (CIS) program that was being offered by the Department of Technology in the School of Science and Technology. The CIS program was more oriented to back-room information systems technology and less focused on developing Information Systems Managers. The program clearly fulfilled a need, and the graduates of the program had no problem in finding employment. The team believed that the CIS program also offered certain courses that could be taken by MIS students. A joint task force consisting of faculty members of the CIS department and the team started work on designing the MIS program. The task force worked under the guidance of the Deans of the School of Science and Technology and the School of Business. The goal was to develop an MIS program that had synergies with the CIS program rather than develop a duplicate program.

The task force began by gathering curriculum requirements for information systems at the following peer institutions: Oklahoma State University, University of Oklahoma, Mississippi State University, Southwest Texas State University, Texas Tech University, University of Central Oklahoma, Central Missouri State University, and University of North Texas. Additionally, information was gathered from model curricula developed by professional societies (AIS and ACM). The program was also discussed with selected members of the External Advisory Committee of the School of Business.

A decision analysis matrix, shown in Appendix 1, was developed to summarize the results of the curriculum analysis. From the matrix, four core areas were identified: Programming, Database Design, Systems Analysis, and Telecommunications. Electives would include, but not be limited to: 
Electronic Commerce, Advanced Telecommunications and Advanced Database. A capstone Management Information Systems course was added to integrate the total learning experience.

The proposed curriculum was circulated to three external reviewers: one each from Indiana University, Bloomington; Miami University, Ohio; and University of Oklahoma, Norman. Recommendations from the reviewers were incorporated in the final proposal sent to the school and university curriculum committees. These committees approved the programs without change.

The curriculum development process is shown in Appendix 2.

\section{THE LEARNING MODEL}

Once the overall curriculum was approved, the team worked on the learning model. Technology in higher education has been likened to "a four-level tower in which each level is progressively more sophisticated than the one below it" $[1,3]$. The tower is shown in Table 1.

The first level represents traditional technologies and the second level is the various pedagogies used in instruction. The third and fourth levels are enhancements to traditional pedagogies and new educational concepts. The upper levels incorporate Information Technology into the classroom and provide for real world projects with real world tools. Each class that was developed was looked at in regards to each level of the learning model.

Level 1: Traditional technologies were the easiest to establish. The sequence of classes was modeled after the largest university in our region. Level 2: Pedagogy was discussed and a $90 \%$ consensus was established by the MIS faculty on what concepts must be taught for each course. Level 3: online Blackboard supplemental sites were established, followed by online sections for several of the courses. Level 4: The CU approach incorporated information technology and some level of grounded learning into each class. Grounded learning resides in the fourth level as described by Ehrmann [1] and "transforms the classroom into a virtual laboratory, involving personal student interaction with real-world events, actors and processes" [4]. This concept led to the use of CASE tools and partnerships with local institutions and businesses to provide real world projects for students. Research by Mosca and Howard [4] indicates that students that completed grounded courses considered the experience more rewarding and motivating than students that only used textprovided cases.

Table 1. Four Levels of Higher Education as Applied to CU School of Business MIS Program

\begin{tabular}{|c|l|l|l|}
\hline Level & \multicolumn{1}{|c|}{ Level Definition } & $\begin{array}{c}\text { CU School of Business MIS } \\
\text { Program Application of Levels }\end{array}$ & \multicolumn{1}{c|}{ Comments } \\
\hline $\mathbf{4}$ & $\begin{array}{l}\text { Information technology in } \\
\text { the classroom } \\
\text { Grounded learning }\end{array}$ & $\begin{array}{l}\text { Acquisition of Systems Architect, a } \\
\text { computer aided software } \\
\text { engineering (CASE) tool }\end{array}$ & $\begin{array}{l}\text { Use of CASE tools } \\
\text { Real world projects for real clients }\end{array}$ \\
\hline $\mathbf{3}$ & $\begin{array}{l}\text { Enhancements to traditional } \\
\text { pedagogies }\end{array}$ & $\begin{array}{l}\text { Development of online classes and } \\
\text { online supplemental sites Testing } \\
\text { using online technologies }\end{array}$ & $\begin{array}{l}\text { Via Blackboard, an online course } \\
\text { web creation service } \\
\text { Use of actual clients }\end{array}$ \\
\hline $\mathbf{1}$ & Pedacation & $\begin{array}{l}\text { Lecture development. } \\
\text { Incorporation of hands-on } \\
\text { components and cases }\end{array}$ & $\begin{array}{l}\text { Conflict resolution of how much } \\
\text { theory vs. how much hands-on }\end{array}$ \\
\hline
\end{tabular}




\section{HOW INDIVIDUAL CLASSES WERE DEVELOPED}

\section{Management Information Systems}

Since this introductory class was to be the cornerstone of the future classes, it needed to be significantly modified to meet the needs of the updated curriculum. The class format was revised to incorporate MIS management skills and behavior modeling consisting of computer demonstrations followed by student hands-on practice. This format is "among the most effective computer training methods" [6] and improves retention. The companion site to the text and the Blackboard assignments provide an e-learning environment for the students. This introductory MIS class continues to evolve.

\section{Database Management}

The first Database Management Class taught at CU used a simple canned exercise that had the students act as database analysts. They managed this canned project by taking the development from a contextual model (Enterprise Model), to a conceptual model (Entity Relationship Diagram), to a logical model to a physical model, and finally to implementation of the database in Microsoft Access. End-of-class student surveys indicated that the behavior modeling of the concepts, combined with physically practicing the skills was a positive experience for the students. Subsequently, an actual project from a client was added. The first client was the CU Graduate Studies program. For this project the students built a database using Systems Architect to replace paper files, word documents and spreadsheets used to maintain MBA student information. The students are currently working on a database for a real estate property management company.

\section{Systems Analysis and Design}

Initially, Database Management was not a prerequisite for the Systems Analysis and Design class. The problem with this was that students were unprepared to participate in a "developmental" project. Students are now required to have additional software training and to complete the Database Management class before they can enroll in the Systems Analysis and Design class. Project management instruction is also offered as part of this class and Microsoft Project is used as an automated project management tool.

\section{Applied Problems in MIS}

The Applied Problems in MIS (Capstone) class is currently in its third iteration. Prerequisites for Capstone include Database Management and Systems Analysis and Design. The students are divided into design teams. They work through a real world problem using real world tools for an actual customer. They must complete ten milestones including the working database with GUI forms and reports. Class projects completed so far include an opportunity tracking system for the business information manager of AST, Inc., a local contracting company, an enrollment and tracking database for the local district Boy Scouts merit badge "camp-o-ree" directors, and an information system to track the individual education program requirements for special education students. The instructor in this class acts only as a facilitator, reference, and grader. There are no lectures. All grades come from the milestones, in process reviews, and the final (working) product. Students must demonstrate good Systems Analysis and Design techniques as well as Database Design techniques learned from previous courses.

\section{FUTURE DIRECTIONS}

Future program changes will require the addition of a number of one-credit hour workshops to enhance the students' proficiency in using programming language software, database software and CASE software. Strong partnerships need to be developed with institutions to provide opportunities for real-world projects in the class and strengthen the internship program. Curriculum updating is an ongoing process that will use input from peer institutions, students, and employers to meet changing needs and incorporate advances in the profession.

\section{Comparison with Peer Institutions}

CU faculty gathered data on eight regional institutions offering an MIS curriculum. Most of these schools had similar core courses requirements such as: Programming, Systems Analysis and Design, Database, and Telecommunications. Additionally, most schools required an introductory MIS course for both MIS majors and all other business majors. While the CU MIS program does offer these same core requirements it is, nonetheless, significantly different in several important ways. The CU program, not only focuses on technical skills, but also excellent management skills. Seeking to meet industry needs, the program utilizes a CASE tool used in both industry and government. While most schools offer 
some familiarization training with a CASE tool, CU requires extensive use of the CASE tool. Additionally, CU developed a Capstone course which required students to demonstrate proficiency across all subject areas in order to meet "real-world" customer requirements. Students in the capstone course work on a project for a real customer. Many of these customers are currently using databases developed by students of the capstone class. The benefit to students is that they gain an appreciation for the many challenges associated with real-world IT projects.

\section{SUMMARY AND CONCLUSIONS}

Three steps were followed in building the revised MIS program: (1) Developing the overall curriculum and getting it approved by the university administration, (2) determining the learning model to be used and (3) developing the individual courses. The fourth step will involve assessment of the program and implementing changes based on the feedback received from the assessment process. This is an ongoing process. The broad steps used in developing the program have been replicated for developing the Associate in Science Degree in Business and can be used to develop new programs or make major revisions of an existing program.

\section{REFERENCES}

1. Ehrmann, S. C. (1998). Using Technology to Transform the College, New Directions for Community Colleges, 21(1), 27-33

2. Kuo, W. \& Deuermeyer, B. (1998). IE2 and IE Curriculum Revisited: Developing a New Undergraduate Program at Texas A\&M University, IIE Solutions, 30(6), 16-22.

3. Leider, S. (August 1, 1998). Successfully Integrating Technology, Eric Digest., Report No: EDO-JC-98-12.

4. Mosca, J. B. \& Howard, L. W. (Nov/Dec97). Grounded Learning: Breathing Life into Business Education, Journal of Education for Business, 73(2), $90-94$.

5. Tracey, K. C. (2002). Developing a Computer Networking Degree: Bridging the Gap between Technology and Business Schools, Journal of American Academy of Business, 2(1), 279-82.

6. Yi, M. Y. \& Davis, F. D. (2001). Improving Computer Training Effectiveness for Decision Technologies: Behavior Modeling and Retention Enhancement, Decision Sciences, 32(3), 521544.

(Appendices on next two pages.) 
Appendix 1. Decision Analysis Matrix

\begin{tabular}{|c|c|c|c|c|c|c|c|c|}
\hline & OSU & OU & MSU & SW TX & $\begin{array}{l}\text { TX } \\
\text { TECH } \\
\end{array}$ & UCM & UCO & UNT \\
\hline \multicolumn{9}{|l|}{ Required Courses } \\
\hline Introduction to MIS & & $\begin{array}{l}\text { MIS } 3113 \\
\text { (CORE) }\end{array}$ & $\begin{array}{l}\text { BIS } 3233 \\
\text { (CORE) }\end{array}$ & $\begin{array}{l}\text { C/S } 3370 \\
\text { (ELEC) }\end{array}$ & $\begin{array}{l}\text { ISQS } \\
2440\end{array}$ & $\begin{array}{l}\text { C/S } 3630 \\
\text { (CORE) }\end{array}$ & $\begin{array}{l}\text { DESCI } \\
4363 \\
\text { (CORE) }\end{array}$ & $\begin{array}{l}\mathrm{BCIS} \\
3690 \\
\text { (CORE) }\end{array}$ \\
\hline Programming I & $\begin{array}{l}\text { MSIS } \\
2203 \\
\text { (CORE) }\end{array}$ & $\begin{array}{l}\text { MIS } 3013 \\
\text { (CORE) }\end{array}$ & $\begin{array}{l}\text { BIS } 1753 \\
\text { (CORE) }\end{array}$ & $\begin{array}{l}\text { C/S } 2324 \\
\text { (CORE }\end{array}$ & $\begin{array}{l}\text { ISQS } \\
2341\end{array}$ & $\begin{array}{l}\text { C/S } 2610 \\
\text { (CORE) }\end{array}$ & $\begin{array}{l}\text { COMSC } \\
1513 \\
\text { (CORE) }\end{array}$ & \\
\hline $\begin{array}{l}\text { Systems Analysis and } \\
\text { Design }\end{array}$ & $\begin{array}{l}\text { MSIS } \\
4113 \\
\text { (CORE) }\end{array}$ & $\begin{array}{l}\text { MIS } 4513 \\
\text { (CORE) }\end{array}$ & & & $\begin{array}{l}\text { ISQS } \\
4358\end{array}$ & $\begin{array}{l}\text { C/S } 3660 \\
\text { (CORE) }\end{array}$ & $\begin{array}{l}\text { DESCI } \\
4163 \\
\text { (CORE) }\end{array}$ & $\begin{array}{l}\text { BCIS } \\
4610 \\
\text { (CORE) }\end{array}$ \\
\hline Database Management & $\begin{array}{l}\text { MSIS } \\
4013 \\
\text { (CORE) }\end{array}$ & $\begin{array}{l}\text { MIS } 4533 \\
\text { (CORE) }\end{array}$ & & & $\begin{array}{l}\text { ISQS } \\
3348\end{array}$ & $\begin{array}{l}\text { C/S } 3650 \\
\text { (CORE) }\end{array}$ & $\begin{array}{l}\mathrm{DESCl} \\
4263 \\
\text { (CORE) }\end{array}$ & $\begin{array}{l}\mathrm{BCIS} \\
4620 \\
\text { (CORE) }\end{array}$ \\
\hline $\begin{array}{l}\text { Data Communications/ } \\
\text { Telecommunications }\end{array}$ & $\begin{array}{l}\text { MSIS } \\
4513 \\
\text { (CORE) }\end{array}$ & $\begin{array}{l}\text { MIS } 4523 \\
\text { (CORE) }\end{array}$ & & & $\begin{array}{l}\text { ISQS } \\
3349\end{array}$ & $\begin{array}{l}\text { C/S } 3605 \\
\text { (CORE) }\end{array}$ & $\begin{array}{l}\mathrm{C} / \mathrm{S} \quad 4665 \\
\text { (ELEC) }\end{array}$ & $\begin{array}{l}\text { BCIS } \\
4680 \\
\text { (CORE) }\end{array}$ \\
\hline \multicolumn{9}{|l|}{ Elective Credit } \\
\hline $\begin{array}{l}\text { Advanced } \quad \text { Database } \\
\text { Management }\end{array}$ & $\begin{array}{l}\text { MSIS } \\
5643 \\
\text { (ELEC) }\end{array}$ & & & & & & & \\
\hline Programming II & $\begin{array}{l}\text { MSIS } \\
3203 \\
\text { (CORE) }\end{array}$ & $\begin{array}{l}\text { MIS } 3033 \\
\text { (CORE) }\end{array}$ & $\begin{array}{l}\text { BIS } 3733 \\
\text { (CORE) }\end{array}$ & $\begin{array}{l}\text { C/S } 2731 \\
\text { (CORE) }\end{array}$ & $\begin{array}{l}\text { ISQS } \\
3346\end{array}$ & $\begin{array}{l}\text { C/S } 3620 \\
\text { (CORE) }\end{array}$ & $\begin{array}{l}\text { COMSC } \\
1713 \\
\text { (CORE) } \\
\end{array}$ & \\
\hline $\begin{array}{l}\text { Advanced } \\
\text { Telecommunications }\end{array}$ & & $\begin{array}{l}\text { MIS } 4223 \\
\text { (ELEC) }\end{array}$ & & $\begin{array}{l}\text { C/S } 3395 \\
\text { (ELEC) }\end{array}$ & & $\begin{array}{l}\text { C/S } 4665 \\
\text { (ELEC) }\end{array}$ & & \\
\hline $\begin{array}{l}\text { Electronic Commerce and } \\
\text { Web Page Design }\end{array}$ & & $\begin{array}{l}\text { MIS } 4483 \\
\text { (ELEC) }\end{array}$ & & & & & & \\
\hline Project Management & & & & & $\begin{array}{l}\text { ISQS } \\
4350\end{array}$ & $\begin{array}{l}\text { C/S } 3680 \\
\text { (CORE) }\end{array}$ & $\begin{array}{l}\mathrm{C} / \mathrm{S} \quad 4675 \\
\text { (ELEC) }\end{array}$ & \\
\hline Information Systems Seminar & $\begin{array}{l}\text { MSIS } \\
6200 \\
\text { (ELEC) }\end{array}$ & $\begin{array}{l}\text { MIS } \\
(4170)\end{array}$ & $\begin{array}{l}\text { BIS } 4473 \\
\text { (ELEC) }\end{array}$ & & & $\begin{array}{l}\text { C/S } 4635 \\
\text { (ELEC) }\end{array}$ & $\begin{array}{l}\text { DESCI } \\
4913 \\
\text { (ELEC) }\end{array}$ & $\begin{array}{l}\text { BCIS } \\
4670 \\
\text { (ELEC) }\end{array}$ \\
\hline $\begin{array}{l}\text { te: Different universities } h \\
\text { en grouped together. }\end{array}$ & & & & & & & & \\
\hline
\end{tabular}


Appendix 2. Curriculum Development Process

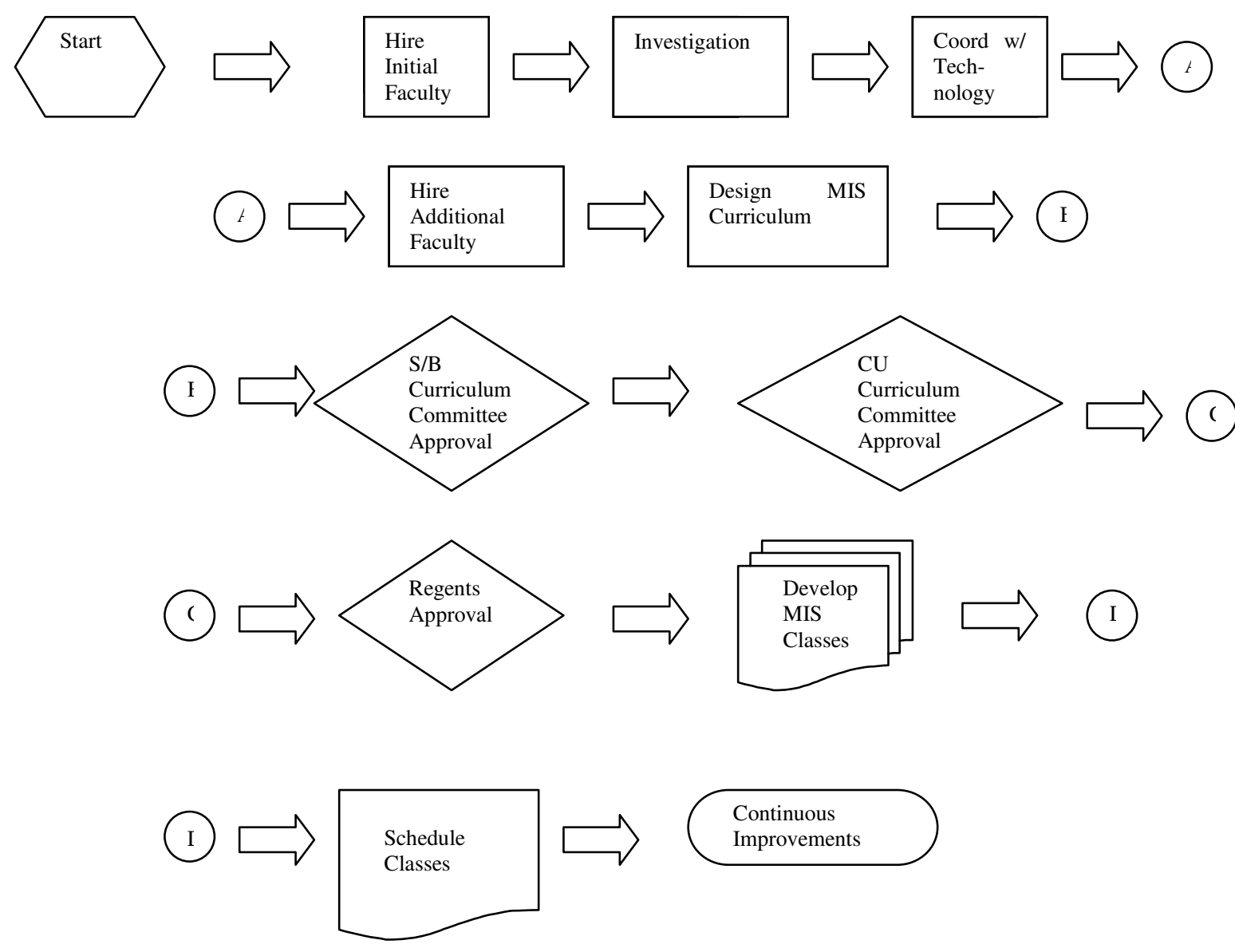

